\title{
ATPase WRNIP1
}

National Cancer Institute

\section{Source}

National Cancer Institute. ATPase WRNIP1. NCI Thesaurus. Code C106311.

ATPase WRNIP1 (665 aa, $72 \mathrm{kDa}$ ) is encoded by the human WRNIP1 gene. This protein is involved in both ATP hydrolysis and DNA replication. 